University of Nebraska - Lincoln

DigitalCommons@University of Nebraska - Lincoln

US Department of Energy Publications

U.S. Department of Energy

2006

\title{
Changes in Uranium Speciation through a Depth Sequence of Contaminated Hanford Sediments
}

Jeffrey Catalano

Stanford University, catalano@anl.gov

James Mckinley

Pacific Northwest National Laboratory, james.mckinley@pnl.gov

John M. Zachara

Pacific Northwest National Laboratory, john.zachara@pnl.gov

Steve Heald

Pacific Northwest National Laboratory, steve.heald@pnl.gov

Steven Smith

Pacific Northwest National Laboratory, steven.smith@pnl.gov

See next page for additional authors

Follow this and additional works at: https://digitalcommons.unl.edu/usdoepub

Part of the Bioresource and Agricultural Engineering Commons

Catalano, Jeffrey; Mckinley, James; Zachara, John M.; Heald, Steve; Smith, Steven; and Brown, Gordon Jr., "Changes in Uranium Speciation through a Depth Sequence of Contaminated Hanford Sediments" (2006). US Department of Energy Publications. 231.

https://digitalcommons.unl.edu/usdoepub/231

This Article is brought to you for free and open access by the U.S. Department of Energy at DigitalCommons@University of Nebraska - Lincoln. It has been accepted for inclusion in US Department of Energy Publications by an authorized administrator of DigitalCommons@University of Nebraska - Lincoln. 


\section{Authors}

Jeffrey Catalano, James Mckinley, John M. Zachara, Steve Heald, Steven Smith, and Gordon Brown Jr. 


\section{Changes in Uranium Speciation through a Depth Sequence of Contaminated Hanford Sediments}

\author{
J E F F R E G. CATALANO, $*,+$ \\ JAMES P. MCKINLEY, ‡

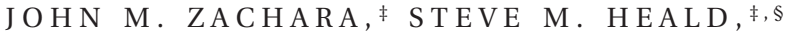 \\ STEVEN C. SMITH, AND $^{\circ}$ \\ G O R D O E. B ROWN, J R. ${ }^{\dagger}, \|$ \\ Department of Geological and Environmental Sciences, \\ Stanford University, Stanford, California 94305, Pacific \\ Northwest National Laboratory, Richland, WA 99354, \\ PNC-CAT, Advanced Photon Source, Argonne National \\ Laboratory, Argonne, IL 60439, and Stanford Synchrotron \\ Radiation Laboratory, SLAC, Menlo Park, CA 94025
}

The disposal of basic sodium aluminate and acidic $\mathrm{U}(\mathrm{VI})-\mathrm{Cu}(\mathrm{II})$ wastes in the now-dry North and South 300 A Process Ponds at the Hanford site resulted in a groundwater plume of $\mathrm{U}(\mathrm{VI})$. To gain insight into the geochemical processes that occurred during waste disposal and those affecting the current and future fate and transport of this uranium plume, the solid-phase speciation of uranium in a depth sequence of sediments from the base of the North Process Pond through the vadose zone to groundwater was investigated using standard chemical and mineralogical analyses, electron and $\mathrm{X}$-ray microprobe measurements, and $\mathrm{X}$-ray absorption fine structure spectroscopy. Nearsurface sediments contained uranium coprecipitated with calcite, which formed due to overneutralization of the waste ponds with base $(\mathrm{NaOH})$. At intermediate depths in the vadose zone, metatorbernite $\left[\mathrm{Cu}\left(\mathrm{UO}_{2} \mathrm{PO}_{4}\right)_{2} \cdot 8 \mathrm{H}_{2} \mathrm{O}\right]$ precipitated, likely during pond operations. Uranium occurred predominantly sorbed onto phyllosilicates in the deeper vadose zone and groundwater; sorbed uranium was also an important component at intermediate depths. Since the calcite-bearing pond sediments have been removed in remediation efforts, uranium fate and transport will be controlled primarily by desorption of the sorbed uranium and dissolution of metatorbernite.

\section{Introduction}

Plutonium production at the Hanford site in Washington State resulted in subsurface contamination at locations of nuclear fuel fabrication, fuel irradiation, strategic radionuclide separation, and waste storage and disposal. One area of concern includes the North and South 300 A Process Ponds in the 300-FF-5 Operable Unit. These waste-disposal ponds lie approximately $100 \mathrm{~m}$ west of the Columbia River at the

\footnotetext{
* Corresponding author present address: Chemistry Division, Argonne National Laboratory, 9700 South Cass Avenue, Argonne, IL 60439, U.S.; phone: (630)252-6679; fax: (630)252-9570; e-mail: catalano@anl.gov.

† Stanford University.

‡ Pacific Northwest National Laboratory.

$\S$ Argonne National Laboratory.

" Stanford Synchrotron Radiation Laboratory.
}

south end of the Hanford site; they received basic sodium aluminate and acidic $\mathrm{U}(\mathrm{VI})-\mathrm{Cu}(\mathrm{II})$ waste streams from the dissolution of nuclear fuel and fuel rod cladding from 1943 to 1975 . The two ponds received approximately $58000 \mathrm{~kg}$ of $\mathrm{U} ; 238000 \mathrm{~kg}$ of $\mathrm{Cu} ; 1156000 \mathrm{~kg}$ of $\mathrm{F}^{-} ; 243000 \mathrm{~kg}$ of $\mathrm{NO}_{3}{ }^{-}$; large amounts of $\mathrm{Al}$ as $\mathrm{Al}(\mathrm{OH})_{4}^{-}$; and lesser undocumented amounts of $\mathrm{Ni}, \mathrm{Cr}, \mathrm{Zn}$, and $\mathrm{P}$. The $\mathrm{pH}$ of the pond water was temporally variable, ranging from 1.8 to 11.4. Sodium hydroxide was frequently added when the $\mathrm{pH}$ was acidic to minimize leaching of $\mathrm{Cu}$ and $\mathrm{U}$ through the vadose zone into the underlying unconfined aquifer and onto the Columbia River. Waste disposal nevertheless resulted in a groundwater plume of U(VI) (Figure 1) that persists to this day (1).

The longevity of the 300 A Hanford groundwater U plume, despite attempted source term removal and copious water flow through the aquifer to the Columbia River, prompted an investigation into the processes controlling the release and transport of uranium at this site (1). The mildly alkaline $\mathrm{pH}$ and relatively high carbonate concentrations of the 300 A porewaters are conditions that normally suppress $U(V I)$ adsorption on iron oxide-poor sediments (2-4), as exist here, yet significant sorbed U(VI) concentrations (up to $250 \mathrm{mg}$ $\mathrm{kg}^{-1}$ of $\mathrm{U}$ ) are observed in the vadose zone (5). This sorbed $\mathrm{U}(\mathrm{VI})$ is believed to sustain the groundwater plume through desorption as meteoric water infiltrates the vadose zone from above and seasonal river stage fluctuations cycle groundwater into the lower vadose zone from below (6). Laboratory studies of U(VI) desorption from the contaminated sediments $(5,6)$ showed unexpectedly slow release, consistent with control by solid-phase dissolution or diffusion. Wang et al. (7) found evidence for U(VI) substitution in calcite at this site, but there is no speciation data that could explain the patterns in desorption noted for samples varying in $U$ concentration and depth in the vadose zone. Within the context of a regulation-driven, scientifically sound remedial action assessment, the identities of solid-phase U chemical species and quantitative information on $U$ desorption kinetics are needed to predict future U(VI) fluxes from the vadose zone to groundwater.

To contribute to a conceptual geochemical model for the site [e.g., (8)] and to provide insights on geochemical controls on desorption, we determined the molecular-level speciation of uranium in a depth sequence of U-contaminated sediments from the 300 A North Process Pond. Standard chemical and mineralogical analyses, X-ray microprobe (XMP) and electron microprobe (EMP) measurements, and X-ray absorption fine structure (XAFS) spectroscopy were applied to a series of samples that progressed from the bottom of the waste pond, through the underlying vadose zone, and to the U groundwater plume. Speciation measurements helped to define the geochemical processes that occurred during waste disposal and the plausible geochemical reactions that determine the current aqueous $U$ concentrations and $U$ containing species. Knowledge of the uranium species formed during disposal and still present, and their depth distribution, provided a basis for interpreting current porewater compositions and for estimating how they might change in the future.

\section{Materials and Methods}

Sediment Collection and Analysis. Contaminated sediments were collected at two different times from the Hanford 300 A Process Pond complex (300-FF-5). The first sampling 


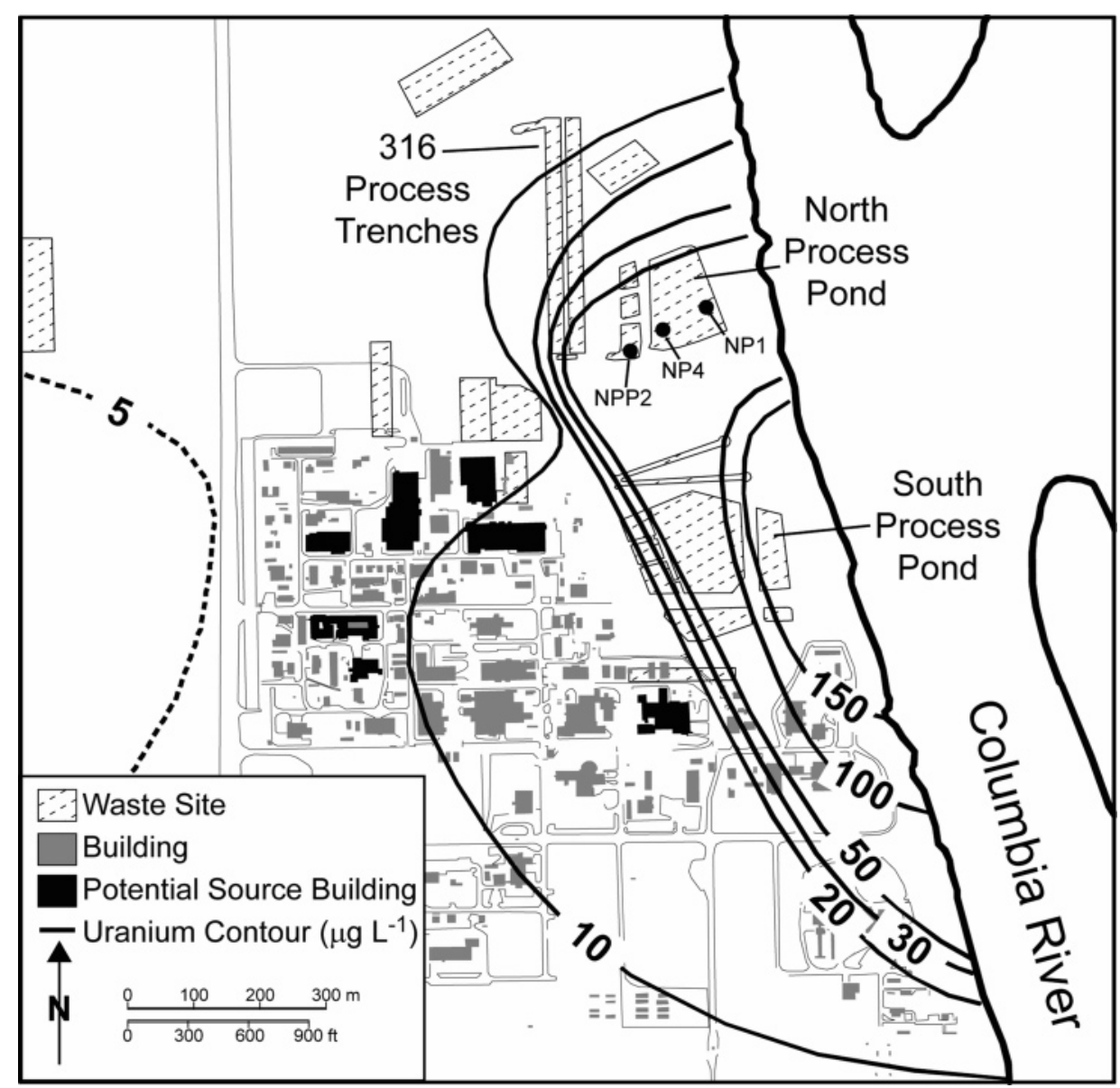

FIGURE 1. Map of Hanford 300 area, showing disposal ponds and other potential sources of uranium contamination and sampling locations. Contours represent uranium concentrations $\left(\mu \mathrm{g} \mathrm{L}^{-1}\right)$ in groundwater in August-September 2001 [the distribution of sampling well locations can be seen in (1)]. The U. S. Environmental Protection Agency's maximum contaminant level (MCL) for uranium is $30 \mu \mathrm{g} \mathrm{L}^{-1}$.

campaign collected sediments directly from the base of the drained North Process Pond in two locations (NP 1 and NP 4). Samples were collected at different depths at both locations, four of which were selected for this study: NP 4-1 (0.3 m depth), NP 4-2 (0.6 m depth), NP 1-4.5 (1.4 m depth), and NP 1-6 (1.8 $\mathrm{m}$ depth). The second sampling campaign occurred after two remediation events removed several meters of material from the pond base. Three samples from this second sampling were selected for this study: NPP 2-0.5 (0.15 m depth), NPP 2-4 (1.2 m depth), and NPP 2-GW (groundwater fines, $3.7 \mathrm{~m}$ depth). All listed depth values are with respect to the ground surface at the time of sampling, and the sample names are related to the sample depth in feet. As the thickness of material removed during remediation was not accurately known, a precise depth relationship could not be established between the NP and NPP samples, although all NPP samples were from several meters below the NP samples. The sediments were dry-sieved to yield a $<2.0 \mathrm{~mm}$ size fraction for more detailed chemical and mineralogical study of the reactive components. Further details on sample collection and analysis are available in the Supporting Information.

Chemical and Mineralogical Characterization. Total elemental composition was determined by energy-dispersive X-ray fluorescence (ED-XRF) spectroscopy (KEVEX 0810A system). A method of peak analysis originally described by Nielson (9) and Nielson and Sanders (10) was used. The inorganic carbon content of the sediments was determined using a Shimadzu carbon analyzer, model TOC-V, SSM5000A. Mineralogical analyses were performed on the bulk sediments and on the clay-sized $(<2.0 \mu \mathrm{m})$ fraction isolated by sedimentation. Powder X-ray diffraction (XRD) measurements were performed with a Philips X'Pert X-ray diffractometer operating in a step scan mode, using $\mathrm{Cu} \mathrm{K \alpha}$ radiation and a graphite monochromator. X-ray diffraction analysis of a clay-sized $(<2 \mu \mathrm{m})$ sediment fraction from this location was reported by Qafoku et al. (6). Sediments from the Hanford 300 A can vary in texture, but the mineralogic composition within specific size fractions (such as sand, silt, or clay) tends to be almost identical in all samples analyzed.

Electron and X-ray Microprobe Measurements. Portions of subsamples of NP 4-1, NPP 2-0.5, and NPP 2-4 were prepared for and examined by EMP as described previously (7). XMP measurements were made at beamline 20-ID (PNCCAT) at the Advanced Photon Source (APS). The incident X-ray beam was focused using a pair of Kirkpatrick-Baez mirrors, and the incident beam was monochromatized using a Si(111) double-crystal monochromator. X-ray fluorescence was measured using an energy-dispersive solid-state Ge detector.

XAFS Data Collection and Analysis. For XAFS analysis, 200-300 mg of each sediment sample was packed in a Teflon sample holder, sealed with $25 \mu \mathrm{m}$ Kapton tape, and then heat-sealed in a polyethylene bag. U L LII-edge XAFS spectra were measured at room temperature on beamline 11-2 (11) at the Stanford Synchrotron Radiation Laboratory (SSRL) and on beamline 13-BM-C (GSECARS) at the APS. On beamline $11-2$, a cryogenically cooled $\mathrm{Si}(220)$ double-crystal monochromator was used. The collimating mirror before the monochromator, used for harmonic rejection, had a cutoff of 22 $\mathrm{keV} . \mathrm{ASi}(111)$ double-crystal monochromator with the second crystal detuned $\sim 50 \%$ was used on beamline 13-BM-C. 
TABLE 1. Selected Chemical Properties of North Process Pond Sediment Samples

\begin{tabular}{|c|c|c|c|c|}
\hline sample & $\underset{\left(m g ~ \mathbf{k g}^{-1}\right)}{\mathbf{U}}$ & $\begin{array}{c}P \\
\left(m g ~ k g^{-1}\right)\end{array}$ & $\underset{\left(\mathrm{mg} \mathrm{kg}^{-1}\right)}{\mathrm{Cu}}$ & $\begin{array}{l}\mathrm{CaCO}_{3} \\
\text { (wt \%) }\end{array}$ \\
\hline NP 4-1 & 3310 & 7200 & 13960 & 3.20 \\
\hline NP 4-2 & 2390 & 3400 & 4940 & 17.6 \\
\hline NP 1-4.5 & 1880 & 5200 & 32400 & 9.06 \\
\hline NP 1-6 & 390 & 3000 & 5540 & 0.99 \\
\hline NPP 2-0.5 & 238 & 5070 & 8260 & 0.11 \\
\hline NPP 2-4 & 139 & 1970 & 4800 & $<\mathrm{DL}^{a}$ \\
\hline NPP 2-GW & 247 & 2360 & 2730 & $<\mathrm{DL}^{a}$ \\
\hline background $^{b}$ & $\sim 5$ & $\sim 900$ & $\sim 30$ & $<0.5$ \\
\hline
\end{tabular}

Fluorescence yield data were collected using a 30-element (11-2) or a 16-element (13-BM-C) solid-state Ge detector. An yttrium metal foil was mounted between two ionization chambers downstream of the sample for energy calibration; the first inflection point in the yttrium K-edge was set to $17038 \mathrm{eV}$.

XAFS data were processed using the SIXPack (12) interface to the IFEFFIT XAFS analysis package (13). X-ray absorption near-edge structure (XANES) spectra were backgroundsubtracted and normalized to an edge step of one. Phaseshift and backscattering amplitude functions for structural fitting of the extended X-ray absorption fine structure (EXAFS) spectra in SIXPack were generated by FEFF 8.2 (14) from the crystal structures of liebigite $\left[\mathrm{Ca}_{2} \mathrm{UO}_{2}\left(\mathrm{CO}_{3}\right)_{3} \cdot \sim 11 \mathrm{H}_{2} \mathrm{O}\right]$ (15), soddyite $\left[\left(\mathrm{UO}_{2}\right)_{2} \mathrm{SiO}_{4} \cdot 2 \mathrm{H}_{2} \mathrm{O}\right](16)$, and metatorbernite [Cu$\left.\left(\mathrm{UO}_{2} \mathrm{PO}_{4}\right)_{2} \cdot 8 \mathrm{H}_{2} \mathrm{O}\right](17)$, with $\mathrm{Al}$ substituted for $\mathrm{Cu}$. Structural (shell by shell) and linear-combination fitting and principal component analysis (PCA) of the EXAFS data were performed in SIXPack. The applications and limitations of the combined PCA and linear-combination fitting methods to the analysis of EXAFS spectra of environmental samples have been described previously (18). The number of principal components was evaluated by considering spectral variance and reconstruction and the indicator function of Malinowski (19), which minimizes for the approximate number of unique components in a set of spectra. The suitability of reference spectra as fitting components was evaluated through target testing using the SPOIL function (20), which determines whether the use of a reference spectrum in data matrix (i.e., the set of sample spectra) reproduction will result in increased error. SPOIL values of $<1.5$ indicate excellent candidates, 1.5-3 good candidates, 3-4.5 fair candidates, $4.5-6$ poor candidates, and $>6$ unacceptable candidates. The spectra of liebigite, soddyite, $\alpha$-uranophane $\left[\mathrm{Ca}\left(\mathrm{UO}_{2}\right)_{2}\left(\mathrm{SiO}_{3} \mathrm{OH}\right)_{2} \cdot 5 \mathrm{H}_{2} \mathrm{O}\right]$, metatorbernite (21), uraninite $\left[\mathrm{UO}_{2}\right](22), \mathrm{U}(\mathrm{VI})$ sorbed to montmorillonite (23) under similar chemical conditions as seen at this site $(1)$, and metaschoepite $\left[\left(\mathrm{UO}_{2}\right)_{4} \mathrm{O}(\mathrm{OH})_{6} \cdot 5 \mathrm{H}_{2} \mathrm{O}\right]$ (collected for this study) were used as initial potential reference phases. Liebigite, $\alpha$-uranophane, and metatorbernite represent uranyl tricarbonate, uranophane group, and (meta)autunite group minerals, respectively; minerals in each group have generally indistinguishable EXAFS spectra at room temperature (21). Metatorbernite was chosen as the representative of the (meta)autunite group because of high copper concentrations in the sediments.

\section{Results and Discussion}

Mineralogy and Contaminant Concentrations. All samples contained major quartz and plagioclase feldspar, with minor muscovite, chlorite, hornblende, augite, and smectite occurring in qualitatively uniform proportions (Supporting Information, Figure S3). The only significant variation in mineralogy was in the calcite content calculated from XRF and carbon analyses (Table 1), which was greater in the upper pond sediment (NP) samples and decreased to below detection at depth. The uranium concentration correlated positively with the calcite content, with elevated concentrations near the pond surface and lower concentrations (though still above background) at depth. Copper and phosphorus concentrations also decreased with depth but remained above background levels, even in the lowest part of the depth sequence. Other samples were collected from the NPP depth sequence that contained $U$ concentrations that were above background (15.2-89.2 $\mathrm{mg} \mathrm{kg}^{-1}$ ) but which were too low for XAFS analyses.

Distribution and Element Associations of Uranium. The pond sediment (NP 4-1; Figure 2) consisted of clasts of variable overall composition that individually were heterogeneous composites. The abundance maps for $\mathrm{U}, \mathrm{Ca}$, and $\mathrm{Si}$ illustrated the granular nature of the clasts and showed directly that there was little overall correlation among elemental distributions. U occurred in sparsely distributed small inclusions (red), imbedded in a finer-grained substrate permeated by $U$ at lower abundance (blue). Ca had a similar distribution, and $U$ and Ca were associated at the $\mu \mathrm{m}$ scale; they occurred together in microgranular precipitates. The Si distribution was also due to the inclusion of silicate minerals of disparate size and composition in the U- and Ca-bearing material (7). In the vadose zone materials (NPP 2-0.5 and NPP 2-4), the abundance of $U$ was much reduced. A few U-rich inclusions were present (more in NPP 2-0.5 than in NPP 2-4), but most of the U occurred at levels below the EMP detection limit. XMP overlays of $U$ abundance on scanning electron microscopy (SEM) images revealed that $U$ occurred in fine, ubiquitous coatings on silicate clasts (Supporting Information, Figure S4). No significant correspondence of $U$ abundance with that of other elements was observed in EMP analyses. The results were consistent with limited penetration of $U$ from waste fluids into the deep vadose zone.

Uranium Speciation. As the concentration, distribution, and elemental associations of uranium vary with depth, uranium speciation is also expected to vary with depth. However, initial characterization by XANES spectroscopy (Supporting Information, Figure S5) revealed that uranium occurs in all samples primarily as U(VI). At the resolution of the $\mathrm{U} \mathrm{L}_{\mathrm{III}}$-edge XANES spectra $(\sim 0.5 \mathrm{eV})$, the presence of a small $(<10 \%)$ U(IV) component cannot be ruled out.

Although the uranium oxidation state was uniform throughout the depth sequence, inspection of the $\mathrm{U} \mathrm{L} \mathrm{LII-}^{-}$ edge EXAFS spectra (Figure 3) suggested that the chemical speciation of uranium changed systematically with increasing depth. The number of phases present in the samples was evaluated through PCA of the EXAFS spectra; the indicator function minimum occurred for two primary components. However, the two components accounted for only $78 \%$ of the spectral variance and did not satisfactorily reconstruct the spectra of samples NPP 2-0.5, NPP 2-4, and NPP 2-GW, especially in the $k=8-10 \AA^{-1}$ region. Inclusion of a third component improved the reconstructions and accounted for $85 \%$ of the variance. The apparent underestimation of the number of primary components by the indicator function likely occurred because of the similarity of all spectra of U(VI)containing species (inherently low variance) and the occurrence of one phase (metatorbernite) as a major component in only two of the sample spectra (see fitting results below). Selected empirical reference spectra were target-transformed in the two- and three-component systems (Supporting Information, Table S1 and Figures S6 and S7). On the basis of SPOIL values, with two components considered, liebigite was an excellent candidate, and U(VI)-sorbed montmorillonite, metatorbernite, and uranophane were good candidates to represent real species present in the samples. With three components considered, the reference compounds 

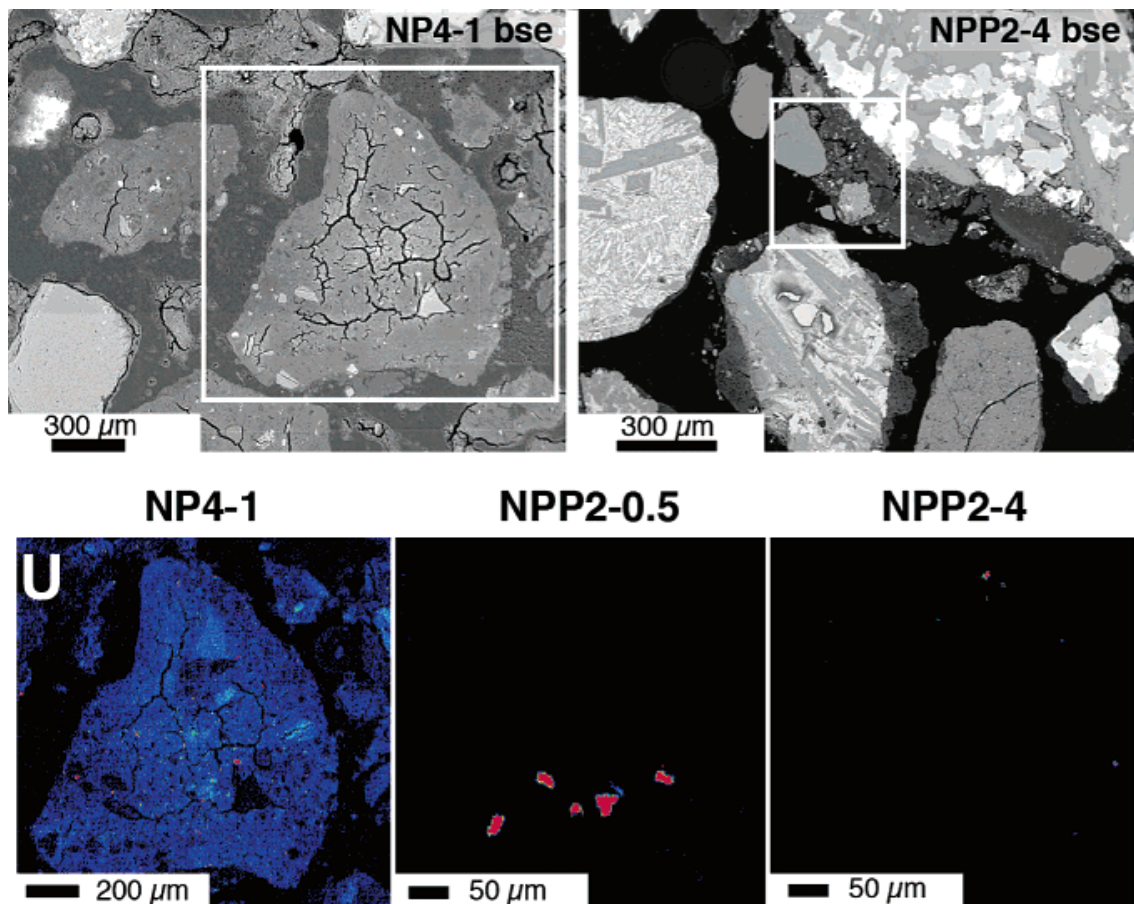
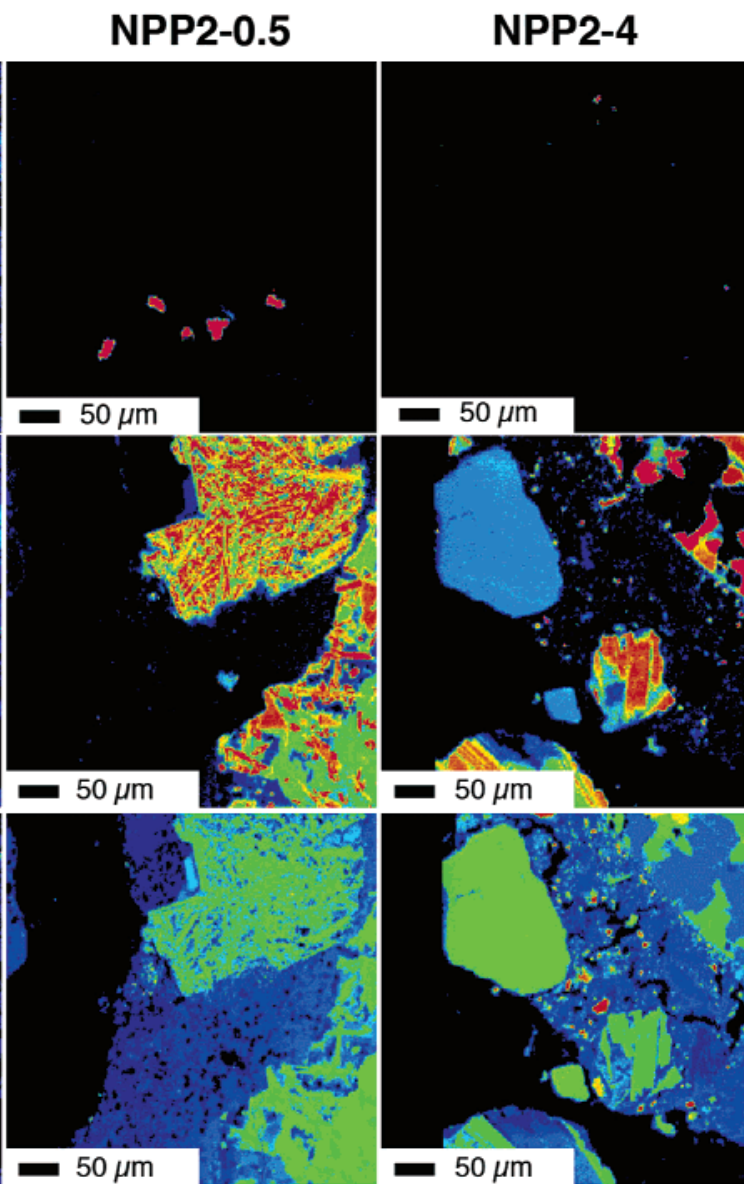

X-ray

\section{Abundance}

cps

\section{0}

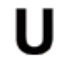

100

0

\section{0}

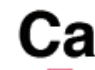

400

0

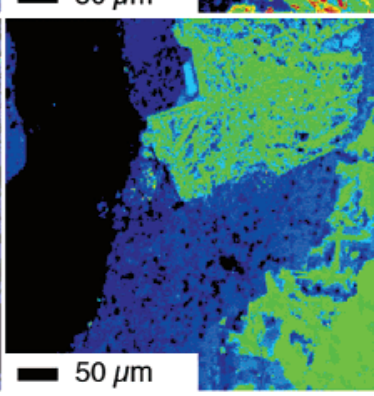

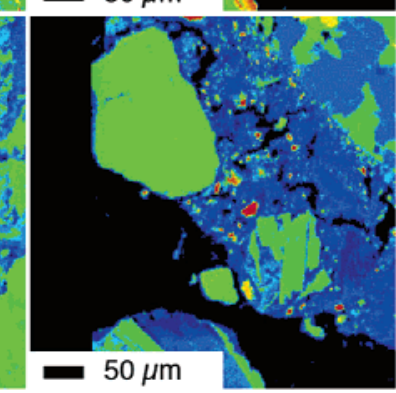

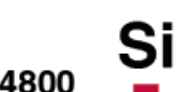

4800

2400

FIGURE 2. Backscattered electron micrographs and elemental abundance maps of samples NP 4-1, NPP 2-0.5, and NPP 2-4. An electron micrograph for sample NPP 2-0.5 was not included as it has a similar appearance to NPP 2-4. Elemental abundances are in X-ray counts per second per nanoamp of electron current. The element abundances for sample NP 4-1 were previously reported by Wang et al. ( 7 ).

were of the same merit, except that metatorbernite was ranked as an excellent candidate, and soddyite was added as a good candidate.

Initial two-species linear-combination fitting of the EXAFS spectra did not produce satisfactory results for any combination of the excellent and good reference spectra, although some spectra were reproduced well. Three-species linearcombination fitting with liebigite, metatorbernite, and U(VI)sorbed montmorillonite as reference standards reproduced the data well (Figure 3a). Although they were indicated as good candidates, soddyite and $\alpha$-uranophane failed to contribute a statistically significant fraction to the spectra in any preliminary fit and were not used in the final analyses.

Although the use of three reference spectra fitted the data well (Figure 3), the component sums (Table 2) were low compared to the expected sum of $\sim 1$. This finding, along with the electron microprobe results and observations in a related study (7), suggested that some of the chosen reference spectra were not correct. Some deviation was expected because of noise and systematic errors in the data. Considering the high solubility of uranyl tricarbonate minerals such as liebigite $(25-27)$ and the partial microscopic association of $\mathrm{U}$ with $\mathrm{Ca}$ (i.e., in calcite) observed in the pond sediments (NP 4-1) by EMP and time-resolved laser-induced fluorescence spectroscopy (TRLFS) (7), a more realistic reference phase was probably uranium coprecipitated with calcite. This hypothesis was supported by recent TRLFS measurements of sample NP 4-1 that produced spectra similar to the spectra of $U$ incorporated into natural and synthetic calcites $(7,28)$. The variability in the EXAFS spectra of U(VI)-bearing calcites (28-32) suggested multiple modes of incorporation. Nevertheless, some of the spectra of U(VI)bearing calcites resembled the spectra of NP 4-1, NP 4-2, and NP 1-4.5 and were similar to the EXAFS spectra of uranyl tricarbonate minerals (e.g., liebigite, one of the fitting components) and solution complexes (e.g, $\left.\left[\mathrm{UO}_{2}\left(\mathrm{CO}_{3}\right)_{3}\right]^{4-}{ }_{(\mathrm{aq})}\right)$, 

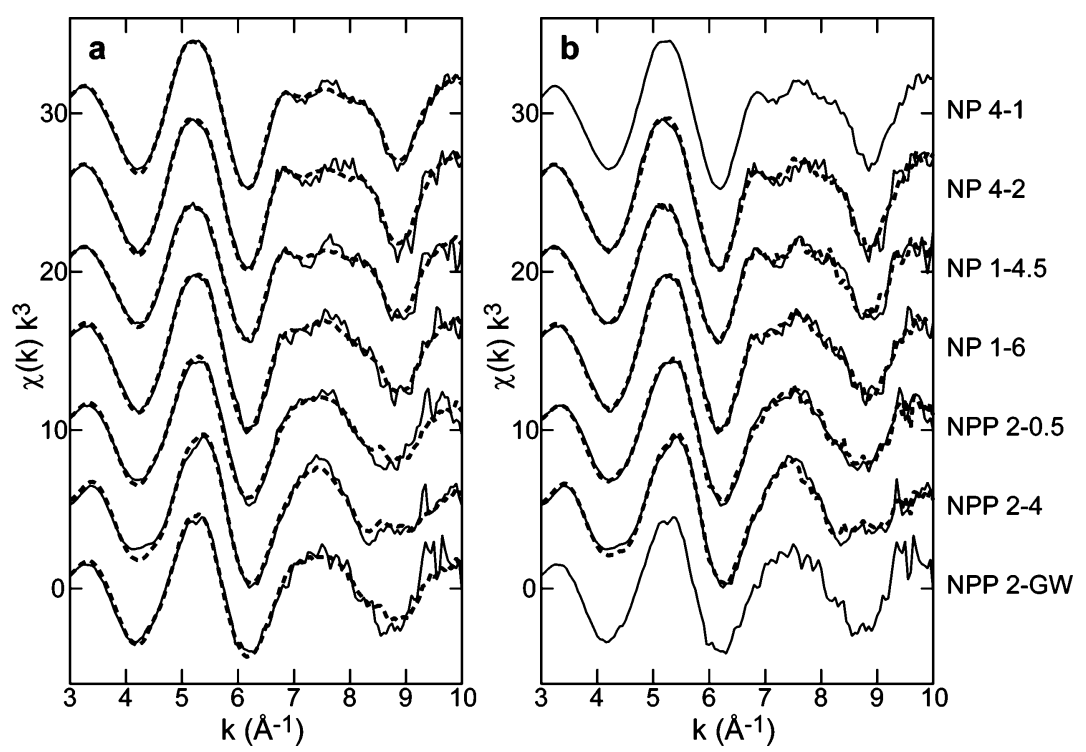

FIGURE 3. Results of EXAFS linear-combination fitting of sample spectra, with the spectra of (a) liebigite, U(VI)-sorbed montmorillonite, and metatorbernite or (b) sample NP 4-1, sample NPP 2-GW, and metatorbernite as reference standards.

TABLE 2. EXAFS Linear-Combination Fitting Results

\begin{tabular}{|c|c|c|c|c|c|c|c|}
\hline & NP 4-1 & NP 4-2 & NP 1-4.5 & NP 1-6 & NPP 2-0.5 & NPP 2-4 & NPP 2-GW \\
\hline \multicolumn{8}{|c|}{ Fit 1} \\
\hline liebigite & $0.49(2)^{a}$ & $0.52(4)$ & $0.45(4)$ & $0.34(4)$ & $0.00(5)$ & $0.00(4)$ & $0.02(6)$ \\
\hline U(VI)-sorbed montmorillonite & $0.42(4)$ & $0.42(6)$ & $0.37(6)$ & $0.54(6)$ & $0.84(8)$ & $0.54(6)$ & $0.87(9)$ \\
\hline metatorbernite & $0.03(2)$ & $0.00(4)$ & $0.00(4)$ & $0.11(4)$ & $0.05(5)$ & $0.41(4)$ & $0.00(6)$ \\
\hline component sumb & 0.92 & 0.94 & 0.83 & 0.98 & 0.89 & 0.95 & 0.89 \\
\hline$\chi^{2 c}$ & 0.05 & 0.16 & 0.17 & 0.18 & 0.28 & 0.18 & 0.42 \\
\hline \multicolumn{8}{|c|}{ Fit 2} \\
\hline NP 4-1 & 1 & $1.00(5)$ & $0.98(4)$ & $0.75(4)$ & $0.16(4)$ & $0.02(4)$ & 0 \\
\hline NPP 2-GW & 0 & $0.03(6)$ & $0.00(5)$ & $0.17(5)$ & $0.63(5)$ & $0.43(5)$ & 1 \\
\hline metatorbernite & 0 & $0.00(3)$ & $0.00(2)$ & $0.15(2)$ & $0.22(2)$ & $0.55(2)$ & 0 \\
\hline component sum & 1 & 1.03 & 0.98 & 1.07 & 1.00 & 1.00 & 1 \\
\hline$\chi^{2}$ & $\mathrm{~N} / \mathrm{A}$ & 0.23 & 0.15 & 0.16 & 0.16 & 0.15 & $\mathrm{~N} / \mathrm{A}$ \\
\hline
\end{tabular}

aside from distortions of some minor spectral features and generally reduced amplitude. This reduction in amplitude suggests that characteristics of the linear-combination fitting results reported above (satisfactory reproduction of the EXAFS data but component sums $<1$ ) would be expected if uranium occurred as a coprecipitate with calcite instead of as a uranyl tricarbonate phase. Furthermore, U(VI) solubility measurements performed on these sediments were not consistent with the presence of a soluble tricarbonate phase (data not shown). The steady-state U(VI) aqueous concentrations were orders of magnitude lower than expected from a uranyl tricarbonate (e.g., liebigite), and significant residual, insoluble $\mathrm{U}(\mathrm{VI})$ remained in the solid phase.

The variability of $U$ incorporation in calcite (see discussion in Supporting Information) makes selecting a spectral standard for U(VI)-bearing calcite from past studies difficult. An alternative approach was to use the spectrum of sample NP 4-1 as a reference standard for U(VI) incorporated into calcite at this site. Similarly, since the spectrum of NPP 2-GW differed from that of a U(VI)-sorbed montmorillonite, and the clay-sized fraction contained multiple phases (6) that might adsorb U (i.e., smectite, illite, muscovite, and chlorite), the use of the spectrum from sample NPP 2-GW as a standard could provide a more realistic reference for the phyllosilicatesorbed component than the use of a U(VI)-sorbed montmorillonite spectrum. Finally, because none of the experimental spectra appeared to represent a sample in which $U$ occurred only in a U(VI) phosphate phase, and since the spectra of the (meta)autunite group minerals are similar (21), the spectrum of metatorbernite appeared to be an adequate reference standard.

Prior to using the spectra of NP 4-1 and NPP 2-GW as components in a linear-combination fit, the spectra were analyzed structurally (see Supporting Information). The best fit to the spectrum of sample NP 4-1 was consistent with U(VI) substituted into calcite. The spectrum of sample NPP 2-GW was best modeled as a uranyl-carbonato ternary surface complex on the edge of a phyllosilicate mineral. Three-species linear-combination fits of the EXAFS spectra with the spectra of samples NP 4-1 and NPP 2-GW and the metatorbernite standard reproduced the data well (Figure $3 b$ ). The average $\chi^{2}$ values from linear-combination fits with these reference standards were lower than in the initial analysis ( 0.17 vs 0.21 ), and the component sums were closer to 1 on average (1.02 \pm 0.04 vs $0.91 \pm 0.05$ ) (Table 2), suggesting that these species are better representations of the phases present. Because it appears the reference spectra used in the initial linearcombination fits were not representative of the true species present, the distribution of phases obtained likely were of poor accuracy, e.g., the identification of U(VI)-sorbed montmorillonite in the upper samples was an artifact. The results from the second round of linear-combination fitting provide a more accurate representation of the true species distribution in these samples. 
Depth Distribution of Uranium Species. The initially acidic conditions of the copper/uranyl nitrate fuel fabrication wastes (33) allowed migration of copper and uranium through both the vadose zone and aquifer system to the Columbia River (34). Anecdotal remarks by site personnel indicated that base (e.g., $\mathrm{NaOH}$ ) was added to the pond waters to neutralize acid and limit the migration of copper to the river, which was evident as green staining around shoreline seeps $(35,36)$. Copper(II) and uranium(VI) exhibit comparable and high mobility under acidic conditions. Both of these ions adsorb strongly to $\mathrm{Fe}, \mathrm{Al}$, and $\mathrm{Mn}$ oxides and layer silicates (mineral components of Hanford sediment) at circumneutral pH [e.g., $(2,3,37-41)]$ and are prone to precipitation as hydroxide, carbonate, and other mineral phases as $\mathrm{pH}$ is increased [e.g., (42-46)]. Neutralization of the pond waters decreased migration of copper and uranium through a combination of near-field precipitation and far-field adsorption processes in both the vadose zone and aquifer sediments (1). These residual sorbed (adsorbed and precipitated) phases were identified by the XAFS measurements in this research.

The subsurface mobility of uranyl, in contrast to $\mathrm{Cu}^{2+}$, increases above $\mathrm{pH} 8$ through formation of anionic uranyl triscarbonato $\left[\mathrm{UO}_{2}\left(\mathrm{CO}_{3}\right)_{3}{ }^{2-}\right.$ (38)] and weakly sorbing calcium uranyl carbonate $\left[\mathrm{Ca}_{2} \mathrm{UO}_{2}\left(\mathrm{CO}_{3}\right)_{3}{ }^{0}(47)\right]$ aqueous complexes. Overneutralization of the pond wastes encouraged the formation of these more-mobile uranium species, which permeated the groundwater system for extended operational periods. In the deeper vadose zone and groundwater, a significant fraction of the dissolved uranium adsorbed to fine-grained materials dominated by the phyllosilicates chlorite and smectite in the coarse-textured sediments (6). These adsorption complexes yielded the XAFS spectra for NPP 2-GW (Figure 3). TRLFS measurements (1) on deeper vadose zone sediments and groundwater fines with sorbed $\mathrm{U}(\mathrm{VI})$ concentrations below those accessible to XAFS showed spectra similar to NPP 2-GW, indicating a common presence of the adsorbed species.

Overneutralization of the waste ponds also left a mineralogic legacy of a high abundance of calcite in the nearsurface sediments (NP 4-1 and 4-2). Some of these pond sediments contained as much as 35 wt \% calcite, concentrations that far exceeded those in comparable Hanford sediments (25). Calcite supersaturation and precipitation occurred in basic waste solutions and porewater through absorption of atmospheric $\mathrm{CO}_{2(\mathrm{~g})}$ and mass-action displacement of $\mathrm{Ca}^{2+}$ by $\mathrm{Na}^{+}$from the phyllosilicate exchanger phase. Uranyl-carbonate complexes evidently coprecipitated with the calcium carbonate under periodically high $\mathrm{pH}$ conditions, yielding the XAFS spectra for samples NP 4-1, 4-2, and 1-4.5. TRLFS measurements on these sediments imply the localization of $\mathrm{U}(\mathrm{VI})$ in both calcite- and aragonite-like structural domains in the calcium carbonate (7). We speculate that the extent, and possibly the rate, of calcite precipitation decreased with depth below the pond interface as the sediment-water reaction reduced the extent of calcite supersaturation by $\mathrm{pH}$ neutralization through silicate mineral dissolution and calcium carbonate precipitation. Our measurements indicated that both the amount and the fractional distribution of uranyl in the carbonate phase decreased with depth.

At intermediate depths in the vadose zone, the $\mathrm{pH}$ and porewater concentrations during pond operation were evidently conducive to the formation of metatorbernite. Unfortunately, vadose zone porewaters were not collected or analyzed during the lifetime of pond operation, so discussions on the formation process of this unusual phase are speculative. It is believed that the $\mathrm{U}, \mathrm{Cu}$, and $\mathrm{P}$ present in this phase all originated from waste releases, possibly at different times. Although the results of the linear-combination fitting of the EXAFS spectra suggested that this phase was present in multiple samples, it only occurred as a major component in sample NPP 2-4 (Table 2). We estimated the original depth of this zone to be 3-4 m below the waste pond. The small U-rich particles observed by EMP in samples NPP 2-0.5 and NPP 2-4 could also be grains of this U(VI)phosphate phase, but the EXAFS data are not of sufficient quality to quantify the distribution of these particles with depth. However, we have confidence that this phase was present, as $\mu$ EXAFS spectroscopy and X-ray microdiffraction measurements on these same samples support the presence of metatorbernite (Yuji Arai, personal communication). Metatorbernite is one (the copper analogue) of the autunite group of minerals that have the general formula $\mathrm{M}\left(\mathrm{UO}_{2}\right)_{2}-$ $\left(\mathrm{PO}_{4}\right)_{2} \cdot\left(8-12 \mathrm{H}_{2} \mathrm{O}\right)$, where $\mathrm{M}$ is a divalent, exchangeable interlayer cation consisting of $\mathrm{Ba}, \mathrm{Ca}, \mathrm{Cu}(\mathrm{II}), \mathrm{Fe}(\mathrm{II}), \mathrm{Mg}, \mathrm{Mn}-$ (II), or $\mathrm{Ni}(48,49)$. It was, therefore, surprising to us that no other mineral phases in this series, such as autunite itself $\left[\mathrm{Ca}\left(\mathrm{UO}_{2}\right)_{2}\left(\mathrm{PO}_{4}\right)_{2} \cdot\left(11 \mathrm{H}_{2} \mathrm{O}\right)\right]$, were observed in the depth sequence, given the high levels of alkali earth cations present in the near-surface sediments (e.g., NP 4-1 and 4-2).

$\mathrm{U}(\mathrm{VI})$ - phosphates have low solubility $(48,50,51)$, and their formation and presence is believed to limit $U(V I)$ concentrations in vadose zone or aquifer waters (52-54). The localization of metatorbernite at its observed depth suggests that the geochemical conditions (e.g., $\mathrm{pH}$, ion composition/concentration) were inappropriate for precipitation in the calcium carbonate formation zone, or that some of the many other waste chemical constituents inhibited its formation. It is also possible that other reactions in the calcium carbonate zone, such as malachite formation $\left[\mathrm{Cu}_{2}(\mathrm{OH})_{2} \mathrm{CO}_{3}\right]$ (observed by X-ray microdiffraction, unpublished data) and phosphate precipitation (as a calcite coprecipitate, a distinct calcium phosphate phase such as brushite, or an $\mathrm{Al}$-phosphate such as augellite), lowered $\mathrm{Cu}$ and $\mathrm{P}$ activities below those necessary for metatorbernite nucleation and formation.

Torbernite and metatorbernite have been identified in two locations as paragenetic products of uranium ore weathering $(48,52,55)$. In both of these locations, metatorbernite was significantly undersaturated with currently circulating groundwaters, indicating synthesis under different geochemical conditions. Murakami et al. $(52,55)$ suggested a surface precipitation formation mechanism in physically isolated microenvironments where $\mathrm{U}, \mathrm{Cu}$, and $\mathrm{P}$ were concentrated by sorption to ferrihydrite, a weathering product of chlorite. Recrystallization of ferrihydrite was proposed to drive metatorbernite precipitation over extended time periods by sustained release of the necessary cations and anions. These conditions do not appear to have been met within the Hanford process-pond environment. Our observation of metatorbernite as a relatively rapidly formed product of nuclear waste release is unique, and continued research at this site seeks to identify plausible formation conditions and mechanisms, which appear to be complex.

Implications for Future Uranium Transport. Excavation as part of source term removal and remediation efforts at the site removed much of the uranium associated with calcite. Because adsorbed $U(V I)$ is the dominant uranium species in the remaining contaminated sediments, adsorption/desorption processes will dominate the future fate and transport of uranium at the site, although the presence of other forms of uranyl microprecipitates cannot be fully discounted from our analyses. Local groundwater has $\mathrm{Ca}^{2+}$ and $\mathrm{CO}_{3}{ }^{2-}$ concentrations close to saturation with respect to calcite (6). These species readily complex U(VI) $(56,57)$, inhibiting its reaction with solid phases and bacteria, promoting desorption, and increasing its transport potential $(58,59)$. Thus, conditions are favorable for desorption of $\mathrm{U}(\mathrm{VI})$ to continue, and the groundwater uranium plume may be sustained soon if sufficient volumes of water contact the contaminated sediments through vadose zone recharge or water table 
fluctuations. Additional kinetic studies of U(VI) adsorption and desorption processes at the Hanford site, like the studies performed on sediments from the nearby South Process Pond (6), will shed light on the time scales for, and concentration expected from, uranium desorption.

\section{Acknowledgments}

This research was supported by the U.S. DOE, Office of Biological and Environmental Research Environmental Sciences Program (EMSP) through DOE-EMSP Grant FG07ER0263495 to Stanford University and project \#86748 to the Pacific Northwest National Laboratory. Contaminated samples from Hanford's 300 A were collected and chemically and mineralogically characterized by the Hanford Remediation and Closure Science Project. We thank John Bargar (SSRL), Joe Rogers (SSRL), and Matt Newville (GSECARS) for their beamline support during data collection. SSRL and APS are national user facilities operated on behalf of the DOE Office of Basic Energy Sciences. GSECARS is supported by National Science Foundation-Earth Sciences (EAR-0217473), DOEGeosciences (DE-FG02-94ER14466), and the State of Illinois. We also thank Yuji Arai and James Davis of the U. S. Geological Survey for sharing their results on the identification of metatorbernite in sample NPP 2-4 that aided in the interpretation of results herein. Comments from four anonymous reviewers improved this manuscript.

\section{Supporting Information Available}

Additional text, figures, and tables are included in the Supporting Information, including details of sample collection, images of the sample location, powder XRD data, an SEM/XMP overlay image, XANES data, PCA target testing results, and structural fitting of the EXAFS spectra of samples NP 4-1 and NPP 2-GW. This material is available free of charge via the Internet at http://pubs.acs.org.

\section{Literature Cited}

(1) Zachara, J. M.; Davis, J. A.; Liu, C.; McKinley, J. P.; Qafoku, N. P.; Wellman, D. M.; Yabusaki, S. B. Uranium Geochemistry in Vadose Zone and Aquifer Sediments from the 300 Area Uranium Plume; PNNL-15121; Pacific Northwest National Laboratory: Richland, WA, 2005

(2) Pabalan, R. T.; Turner, D. R. Uranium(6+) sorption on montmorillonite: Experimental and surface complexation modeling study. Aquat. Geochem. 1997, 2, 203-226.

(3) Pabalan, R. T.; Turner, D. R.; Bertetti, F. P.; Prikryl, J. D. Uranium ${ }^{\text {VI }}$ sorption onto selected mineral surfaces: Key geochemical parameters. In Adsorption of Metals by Geomedia; Jenna, E. A., Ed.; American Press: San Diego, CA, 1998; pp 99-130.

(4) Payne, T. E.; Lumpkin, G. R.; Waite, T. D. Uranium(VI) adsorption on model minerals: Controlling factors and surface complexation modeling. In Adsorption of Metals by Geomedia; Jenne, E. J., Ed.; Academic Press: San Diego, CA, 1998; pp 75-99.

(5) Bond, D. L.; Davis, J. A.; Zachara, J. M. Uranium(VI) dissolution and desorption from contaminated vadose zone sediments, Hanford 300-Area, Washington. Geochim. Cosmochim. Acta 2006, in press.

(6) Qafoku, N. P.; Zachara, J. M.; Liu, C.; Gassman, P. L.; Qafoku, O. S.; Smith, S. C. Kinetic desorption and sorption of U(VI) during reactive transport in a contaminated Hanford sediment. Environ. Sci. Technol. 2005, 39, 3157-3165.

(7) Wang, Z.; Zachara, J. M.; McKinley, J. P.; Smith, S. C. Cryogenic laser induced U(VI) fluorescence studies of a U(VI) substituted natural calcite: Implications to U(VI) speciation in contaminated Hanford sediments. Environ. Sci. Technol. 2005, 39, 2651-2659.

(8) Davis, J. A.; Yabusaki, S. B.; Steefel, C. I.; Zachara, J. M.; Curtis, G. P.; Redden, G. D.; Criscenti, L. J.; Honeyman, B. D. Assessing conceptual models for subsurface reactive transport of inorganic contaminants. EOS Trans., Am. Geophys. Union 2004, 85, 449 and 455 .

(9) Nielson, K. K. Application of direct peak analysis to energydispersive X-ray fluorescence spectra. X-Ray Spectrom. 1978, 7, $15-22$.
(10) Nielson, K. K.; Sanders, R. W. The SAP3 Computer Program for Quantitative Multielement Analysis by Energy-Dispersive X-ray Fluorescence; Pacific Northwest National Laboratory: Richland, WA, 1982.

(11) Bargar, J. R.; Brown, G. E., Jr.; Evans, I.; Rabedeau, T.; Rowen, M.; Rogers, J. H. A new hard X-ray XAFS spectroscopy facility for environmental samples, including actinides, at the Stanford Synchrotron Radiation Laboratory. In Proceedings of the 2nd Euroconference and NEA Workshop on Speciation, Techniques, and Facilities for Radioactive Materials at Synchrotron Light Sources; Reich, T., Shuh, D. K., Eds.; OECD Nuclear Energy Agency: Issy-les-Moulineaux, France, 2002; pp 169-176.

(12) Webb, S. M. SIXPack: A graphical user interface for XAS analysis using IFEFFIT. Phys. Scr. 2005, T115, 1011-1014.

(13) Newville, M. IFEFFIT: interactive XAFS analysis and FEFF fitting. J. Synchrotron. Radiat. 2001, 8, 322-324.

(14) Ankudinov, A. L.; Bouldin, C. E.; Rehr, J. J.; Sims, J.; Hung, H. Parallel calculation of electron multiple scattering using Lanczos algorithms. Phys. Rev. B: Condens. Matter 2002, 104107.

(15) Mereiter, K. The crystal structure of liebigite, $\mathrm{Ca}_{2} \mathrm{UO}_{2}\left(\mathrm{CO}_{3}\right)_{3}$. $\sim 11 \mathrm{H}_{2} \mathrm{O}$. Tschermaks Mineral. Petrogr. Mitt. 1982, 30, 277-288.

(16) Demartin, F.; Gramaccioli, C. M.; Pilati, T. The importance of accurate crystal-structure determination of uranium minerals. II. Soddyite $\left(\mathrm{UO}_{2}\right)_{2}\left(\mathrm{SiO}_{4}\right) \cdot 2 \mathrm{H}_{2} \mathrm{O}$. Acta Crystallogr., Sect. C 1992, $48,1-4$.

(17) Locock, A. J.; Burns, P. C. Crystal structures and synthesis of the copper-dominant members of the autunite and meta-autunite groups: Torbernite, zeunerite, metatorbernite and metazeunerite. Can. Mineral. 2003, 41, 489-502.

(18) Manceau, A.; Marcus, M. A.; Tamura, N. Quantitative speciation of heavy metals in soils and sediments by synchrotron X-ray techniques. Rev. Mineral. Geochem. 2002, 49, 341-428.

(19) Malinowski, E. R. Determination of number of factors and experimental error in a data matrix. Anal. Chem. 1977, 49, 612617.

(20) Malinowski, E. R. Theory of error for target factor-analysis with applications to mass spectrometry and nuclear magnetic resonance spectrometry. Anal. Chim. Acta 1978, 103, 339-354.

(21) Catalano, J. G.; Brown, G. E., Jr. Analysis of uranyl-bearing phases by EXAFS spectroscopy: Interferences, multiple scattering, accuracy of structural parameters, and spectral differences. Am. Mineral. 2004, 89, 1004-1021.

(22) Pierce, E. M.; Icenhower, J. P.; Serne, R. J.; Catalano, J. G. Experimental determination of $\mathrm{UO}_{2}(\mathrm{cr})$ dissolution kinetics: Effects of solution saturation state and pH. J. Nucl. Mater. 2005, $345,206-218$

(23) Catalano, J. G.; Brown, G. E., Jr. Uranyl adsorption onto montmorillonite: Evaluation of binding sites and carbonate complexation. Geochim. Cosmochim. Acta 2005, 69, 2995-3005.

(24) Serne, R. J.; Brown, C. F.; Schaef, H. T.; Pierce, E. P.; Lindberg, M. J.; Wang, Z.; Gassman, P.; Catalano, J. G. 300 Area Uranium Leach and Adsorption Project: ERC FY01-02 Final Report PNNL-14022; United States Department of Energy, Richland Operations: Richland, WA, 2002.

(25) Alwan, A. K.; Williams, P. A. Aqueous chemistry of uranium minerals. Part 2. Minerals of the liebigite group. Min. Mag. 1980 $43,665-667$.

(26) Finch, R. J. Thermodynamic stabilities of U(VI) minerals: Estimated and observed relationships. In Scientific Basis for Nuclear Waste Management XX; Gray, W. J., Triay, I. R., Eds.; Vol. 465; Materials Research Society: Warrendale, PA, 1997; pp $1185-1192$.

(27) Amayri, S.; Bernhard, G.; Nitsche, H. Solubility of $\mathrm{Ca}_{2}\left[\mathrm{UO}_{2}\left(\mathrm{CO}_{3}\right)_{3}\right]$. $10 \mathrm{H}_{2} \mathrm{O}$, liebigite. In Forschungszentrum Rossendorf Institute of Radiochemistry, Annual Report 1998; Nitsche, H., Bernhard, G., Eds.; Forschungszentrum Rossendorf: Dresden, Germany, 1999; $\mathrm{p} 12$.

(28) Reeder, R. J.; Nugent, M.; Tait, C. D.; Morris, D. E.; Heald, S. M.; Beck, K. M.; Hess, W. P.; Lanzirotti, A. Coprecipitation of uranium(VI) with calcite: XAFS, micro-XAS, and luminescence characterization. Geochim. Cosmochim. Acta 2001, 65, 34913503.

(29) Reeder, R. J.; Nugent, M.; Lamble, G. M.; Tait, C. D.; Morris, D. E. Uranyl incorporation into calcite and aragonite: XAFS and luminescence studies. Environ. Sci. Technol. 2000, 34, 638644.

(30) Kelly, S. D.; Newville, M. G.; Cheng, L.; Kemner, K. M.; Sutton, S. R.; Fenter, P.; Sturchio, N. C.; Spotl, C. Uranyl incorporation in natural calcite. Environ. Sci. Technol. 2003, 37, 1284-1287. 
(31) Elzinga, E. J.; Tait, C. D.; Reeder, R. J.; Rector, K. D.; Donohoe, R. J.; Morris, D. E. Spectroscopic investigation of U(VI) sorption at the calcite-water interface. Geochim. Cosmochim. Acta 2004, 68, 2437-2448.

(32) Reeder, R. J.; Elzinga, E. J.; Tait, C. D.; Rector, K. D.; Donohoe, R. J.; Morris, D. E. Site-specific incorporation of uranyl carbonate species at the calcite surface. Geochim. Cosmochim. Acta 2004, $68,4799-4808$.

(33) Clukey, H. V. 300 Area Radioactive Liquid Waste Streams Disposal; HW-32762; General Electric, Hanford Atomic Products Operation: Richland, WA, 1954.

(34) Wells, G. W. Chemicals Discharged to the Columbia River from DUN Facilities Fiscal Year 1967; DUN-3032; Douglas United Nuclear, Inc.: Richland, WA, 1967.

(35) Dennison, D. I.; Sherwood, D. R.; Young, J. S. Status Report on Remedial Investigation of the 300 Area Process Ponds; PNL-6442; Pacific Northwest Laboratory: Richland, WA, 1989.

(36) Young, J. S.; Fruland, R. M.; Fruchter, J. S. Data Compilation Task Report for the Source Investigation of the 300-FF-1 Operable Unit Phase I Remedial Investigation; PNL-7241; Pacific Northwest Laboratory: Richland, WA, 1990.

(37) Stadler, M.; Schindler, P. W. Modeling of $\mathrm{H}^{+}$and $\mathrm{Cu}^{2+}$ adsorption on calcium-montmorillonite. Clays Clay Miner. 1993, 41, 288296.

(38) Waite, T. D.; Davis, J. A.; Payne, T. E.; Waychunas, G. A.; Xu, N. Uranium(VI) adsorption to ferrihydrite: Application of a surface complexation model. Geochim. Cosmochim. Acta 1994, 58, 5465-5478.

(39) Turner, G. D.; Zachara, J. M.; McKinley, J. P.; Smith, S. C. Surfacecharge properties and $\mathrm{UO}_{2}{ }^{2+}$ adsorption of a subsurface smectite. Geochim. Cosmochim. Acta 1996, 60, 3399-3414.

(40) Buerge-Weirich, D.; Hari, R.; Xue, H. B.; Behra, P.; Sigg, L. Adsorption of $\mathrm{Cu}, \mathrm{Cd}$, and $\mathrm{Ni}$ on goethite in the presence of natural groundwater ligands. Environ. Sci. Technol. 2002, 36, 328-336.

(41) Undabeytia, T.; Nir, S.; Rytwo, G.; Serban, C.; Morillo, E.; Maqueda, C. Modeling adsorption-desorption processes of $\mathrm{Cu}$ on edge and planar sites of montmorillonite. Environ. Sci. Technol. 2002, 36, 2677-2683.

(42) Finch, R. J.; Ewing, R. C. The corrosion of uraninite under oxidizing conditions. J. Nucl. Mater. 1992, 190, 133-156.

(43) Pearcy, E. C.; Prikryl, J. D.; Murphy, W. M.; Leslie, B. W. Alteration of uraninite from the Nopal I deposit, Peña Blanca District, Chihuahua, Mexico, compared to degradation of spent nuclear fuel in the proposed U. S. high-level nuclear waste repository at Yucca Mountain, Nevada. Appl. Geochem. 1994, 9, 713-732.

(44) Bruno, J.; De Pablo, J.; Duro, L.; Figuerola, E. Experimental study and modeling of the $\mathrm{U}(\mathrm{VI})-\mathrm{Fe}(\mathrm{OH})_{3}$ surface precipitation/ coprecipitation equilibria. Geochim. Cosmochim. Acta 1995, 59, 4113-4123

(45) Hidmi, L.; Edwards, M. Role of temperature and $\mathrm{pH}$ in $\mathrm{Cu}(\mathrm{OH})_{2}$ solubility. Environ. Sci. Technol. 1999, 33, 2607-2610.
(46) Giammar, D. E.; Hering, J. G. Time scales for sorptiondesorption and surface precipitation of uranyl on goethite. Environ. Sci. Technol. 2001, 35, 3332-3337.

(47) Fox, P. M.; Davis, J. A.; Zachara, J. M. The effect of calcium on aqueous uranium(VI) speciaton and adsorpton to ferrihydrite and quartz. Geochim. Cosmochim. Acta 2006, in press.

(48) Magalhaes, M. C. F.; Pedrosa de Dejesus, J.; Williams, P. A. The chemistry of uranium dispersion in groundwaters at the Pinhal do Souto Mine, Portugal. Inorg. Chim. Acta 1985, 109, 71-78.

(49) Frost, R. L.; Kristof, J.; Weier, M. L.; Martens, W. N.; Horvath, E. Thermal decomposition of metatorbernite-A controlled rate thermal analysis study. J. Therm. Anal. Calorim. 2005, 79, 721725.

(50) Sandino, A.; Bruno, J. The solubility of $\left(\mathrm{UO}_{2}\right)_{3}\left(\mathrm{PO}_{4}\right)_{2} \cdot 4 \mathrm{H}_{2} \mathrm{O}_{(\mathrm{s})}$ and the formation of U(VI) phosphate complexes: Their influence in uranium speciation in natural waters. Geochim. Cosmochim. Acta 1992, 56, 4135-4145.

(51) Sowder, A. G.; Clark, S. B.; Fjeld, R. A. The impact of mineralogy in the $\mathrm{U}(\mathrm{VI})-\mathrm{Ca}-\mathrm{PO}_{4}$ system on the environmental availability of uranium. J. Radioanal. Nucl. Chem. 2001, 248, 517-524.

(52) Murakami, T.; Ohnuki, T.; Isobe, H.; Sato, T. Mobility of uranium during weathering. Am. Mineral. 1997, 82, 888-899.

(53) Fuller, C. C.; Bargar, J. R.; Davis, J. A.; Piana, M. J. Mechanisms of uranium interactions with hydroxyapatite: Implications for groundwater remediation. Environ. Sci. Technol. 2002, 36, 158165.

(54) Jerden, J. L.; Sinha, A. K.; Zelazny, L. Natural immobilization of uranium by phosphate mineralization in an oxidizing saprolitesoil profile: Chemical weathering of Coles Hill uranium deposit, Virginia. Chem. Geol. 2003, 199, 129-157.

(55) Murakami, T.; Sato, T.; Ohnuki, T.; Isobe, H. Field evidence for uranium nanocrystallization and its implications for uranium transport. Chem. Geol. 2005, 221, 117-126.

(56) Kalmykov, S. N.; Choppin, G. R. Mixed $\mathrm{Ca}^{2+} / \mathrm{UO}_{2}{ }^{2+} / \mathrm{CO}_{3}{ }^{2-}$ complex formation at different ionic strengths. Radiochim. Acta 2000, 88, 603-606.

(57) Bernhard, G.; Geipel, G.; Reich, T.; Brendler, V.; Amayri, S.; Nitsche, H. Uranyl(VI) carbonate complex formation: Validation of the $\mathrm{Ca}_{2} \mathrm{UO}_{2}\left(\mathrm{CO}_{3}\right)_{3}$ (aq.) species. Radiochim. Acta 2001, 89, 511-518.

(58) Brooks, S. C.; Fredrickson, J. K.; Carroll, S. L.; Kennedy, D. W.; Zachara, J. M.; Plymale, A. E.; Kelly, S. D.; Kemner, K. M.; Fendorf, $\mathrm{S}$. Inhibition of bacterial U(VI) reduction by calcium. Environ. Sci. Technol. 2003, 37, 1850-1858.

(59) Davis, J. A.; Meece, D. E.; Kohler, M.; Curtis, G. P. Approaches to surface complexation modeling of uranium(VI) adsorption on aquifer sediments. Geochim. Cosmochim. Acta 2004, 68, $3621-3641$.

Received for review October 21, 2005. Revised manuscript received January 31, 2006. Accepted February 13, 2006.

ES0520969 